\title{
Decarbonisation of the electricity sector? CCUS still imperative
}

Fernando Rubiera, Covadonga Pevida

Department of Coal, Energy and Environment

Instituto Nacional del Carbón, INCAR-CSIC, c/Francisco Pintado Fe, 26. 33011 Oviedo. Spain

There is an increasing move, mainly in developed countries, to phase-out coal in the power generation sector. This is particularly evident in many European countries that support Europe's policy to implement a low-carbon economy to comply with the objectives of the Paris Agreement. In this respect, it was remarkably significant the announcement of the UK Government plans to close all coal power plants by 2025 and it was followed by other countries like Austria, Belgium, Denmark, France, Italy, The Netherlands, Portugal and Sweden. While decarbonisation of the economy will have positive environmental implications to our society, the reduction of coal utilisation will be accompanied by the inevitable closure of mines in regions that have traditionally relied on coal as primary energy source. In Europe 41 regions in 12 Member States are actively mining coal, with about 185,000 direct employments. This scenario has prompted the need to launch initiatives to support the transformation and diversification of coal and carbon intensive regions. An ongoing action by the European Commission, the Platform on Coal Regions in Transition, kicked-off in Strasbourg on December $11^{\text {th }} 2017$ to help regions with coal mining activities identify, develop and implement projects with the potential to kick-start a viable economic and technological transformation, and to enable multi-stakeholder dialogue on policy framework and regulations. ${ }^{1}$

Such type of actions is worth of firm support but they are taking place in developed countries; non-OECD countries are still mostly dependent on coal for energy. Coal consumption accounts for over $75 \%$ for non-OECD countries, with China and India leading with a share of 50 and $11 \%$, respectively. ${ }^{2}$ India is a country with plenty of coal reserves, a population likely to surpass that of China, and a rapidly growing economy. These facts anticipate that India may become the world largest carbon emitter in the near future. According to IEA preliminary estimates, global energy demand grew by $2.1 \%$ in 2017, with China and India representing more than $40 \%$ of that increase. ${ }^{3}$ There was a $1 \%$ rise in coal demand driven mostly by an increase in electricity generation by coal-fired utilities. Consistently, the global energy-related $\mathrm{CO}_{2}$ emissions grew by $1.4 \%$, with a historic high of $32.5 \mathrm{Gt}$ that indicates a trend reversal in the stable levels achieved since $2014 .{ }^{4}$ However, data must be handled with care; for 
instance, $\mathrm{CO}_{2}$ emissions in the European Union rose by $1.5 \%$ in 2017, and this increase is mainly attributed to robust growth in oil and gas use. ${ }^{3}$

GHG global emissions need to peak around 2020 and be brought to zero shortly after the middle of this century, as specified in Article 4 of the Paris Agreement. However, time is going by without reaching that peak, jeopardising compliance with the ambitious objectives of the Paris Agreement: limit the global temperature rise to well below $2{ }^{\circ} \mathrm{C}$ above preindustrial levels, while pursuing efforts to limit the increase to $1.5^{\circ} \mathrm{C}$. Efforts worldwide to achieve the decarbonisation objectives are nevertheless significant; in a statement published on April $5^{\text {th }} 2017,{ }^{5}$ the Union of the Electricity Industry (EURELECTRIC), which represents 3,500 companies across Europe, announced that they will build no new coal-fired power plants in the European Union after 2020. Twenty-six of the 28 EU Member States have signed onto the initiative, but the statement was not supported by the Polish and Greek member associations. Nonetheless, greenfield coal-fired power plants are inexorably going to be built in coal dependent countries like China, India, Vietnam or Indonesia, but also in non-coal producers like Japan as well as in European countries; Poland and Greece are the only two EU countries planning to invest in new-build coal-fired power plants.

In the 2DS depicted by the IEA, more than half of CCS deployment through 2050 has to take place in the power generation sector, and predominantly in coal fired plants. In the 1.5DS, the net negative $\mathrm{CO}_{2}$ emissions target must be realised by mid-century; biomass, as single fuel or co-utilised with coal and natural gas, combined with carbon capture utilisation and storage (Bio-CCUS) is one of the few options that holds the potential to reach negative $\mathrm{CO}_{2}$ emissions and it is likely to be required to meet the stringent climate targets. ${ }^{6}$

Decarbonisation of the energy sector will be region-specific but CCUS will unavoidably need to be deployed worldwide to meet the 1.5DS targets even if a carbon neutral power supply is implemented by the middle of this century. Trump's Administration unexpected announcement of incentives to CCUS deployment in US (45Q tax credit) certainly supports the Paris Agreement objectives but then, what is going on in Europe? a different pace to $\mathrm{CO}_{2}$ emissions abatement is foreseen due to the current building of new coal-fuelled power plants without carbon capture units.

Thus, one has to go some years back and quote other Editorials of this Journal: In the first issue of GHG (Feb 2011) the urgent need to accelerate progress in CCS was pointed out; in December 2012 another editorial title read 'CCS: doing more, but still not enough'; at this 
point we have to refer to our previous editorial in GHG (April 2013) and conclude that 'the pace of progress in CCUS is still frustratingly slow'.

\section{References}

1. European Commission, Coal Regions in Transition Platform [Online]. Available at: https://ec.europa.eu/energy/en/events/conference-coal-regions-transition-platform 2. British Petroleum, BP Statistical Review of World Energy 2017 [Online]. Available at: https://www.bp.com/en/global/corporate/energy-economics/statistical-review-of-worldenergy/downloads.html

3. IEA, Global Energy and $\mathrm{CO}_{2}$ Status Report 2017 [Online]. Available at: https://www.iea.org/geco/ 4. Enerdata, Rise in global energy-related $\mathrm{CO}_{2}$ emissions in 2017 [Online]. Available at: https://www.enerdata.net/publications/executive-briefing/global-increase-co2-emissions-2017.html.. 5. EURELECTRIC, European Electricity Sector gears up for the Energy Transition [Online]. Available at:

https://cdn.eurelectric.org/media/2128/eurelectric_statement_on_the_energy_transition_2-2017-0300250-01-e-h-E321F960.pdf

6. IEAGHG, Potential for biomass and carbon capture and storage, Report 2011/06, [Online], Available at: http://www.ieaghg.org/docs/General_Docs/Reports/2011-06.pdf 